
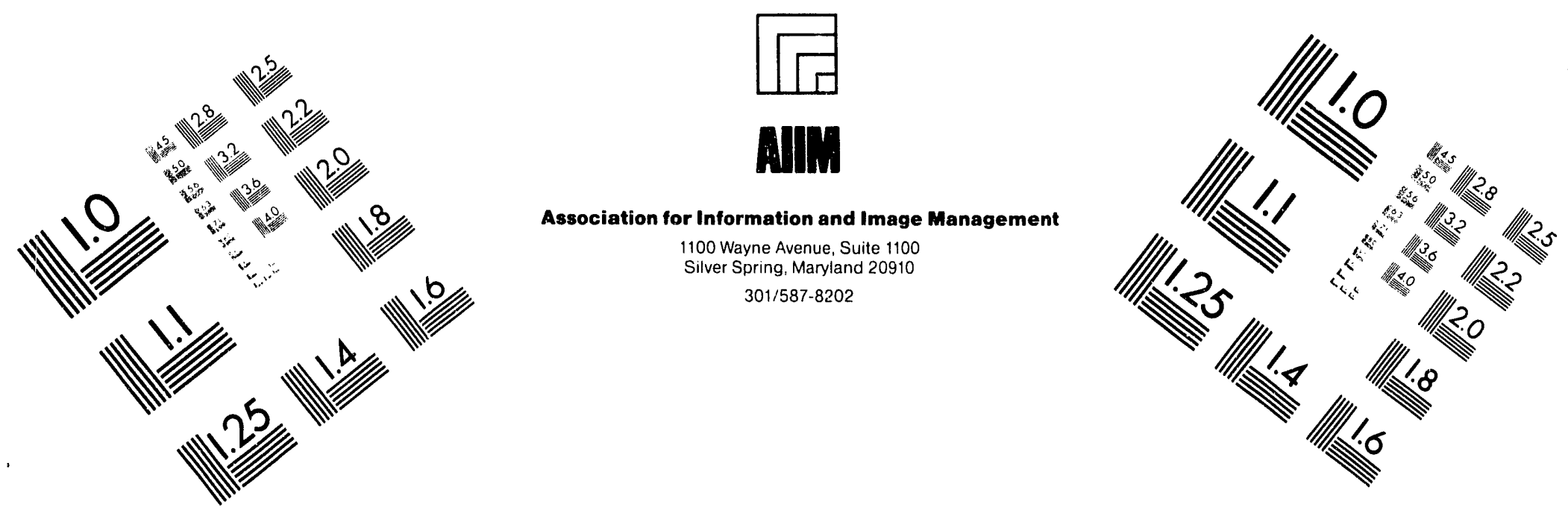

\title{
Centimeter
}

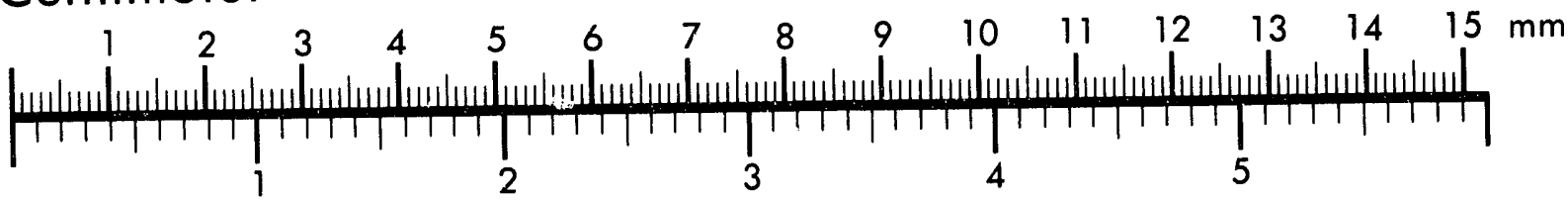
Inches
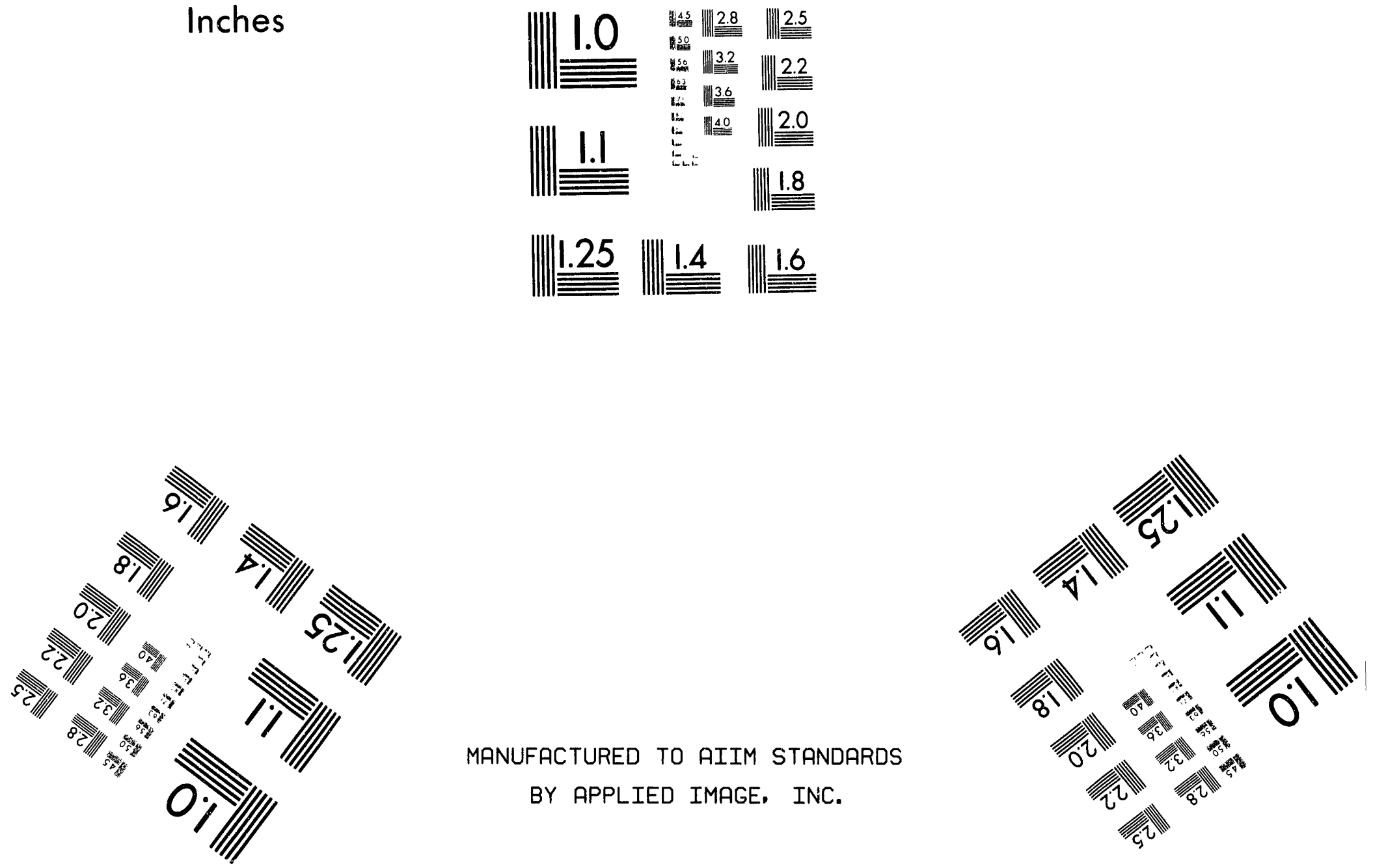

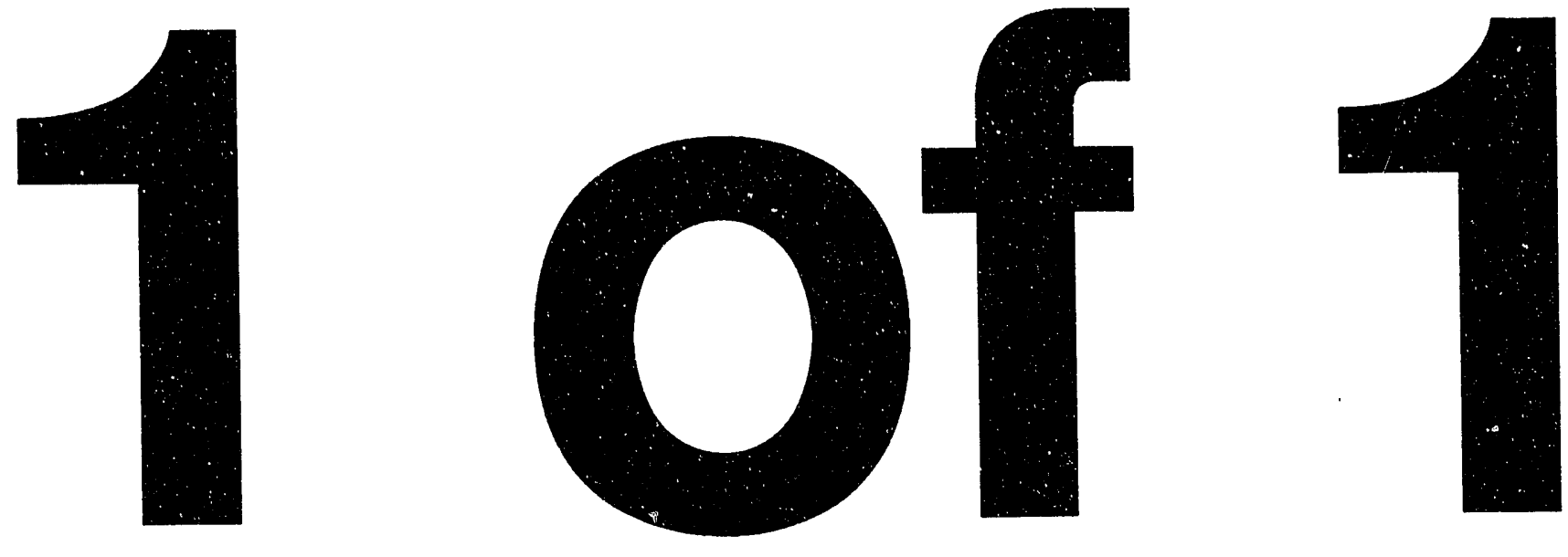


\section{Performance Reports}

Title: Synthesis and Evaluation of Boron Compounds for Neutron Capture Therapy of Malignant Brain Tumors

Contract No: Department of Energy

DE-FG02-90ER60972

Project Period: May 1, 1990 - October 26, 1992

Principal Investigator: Albert H. Soloway, Ph.D.

Co-Principal Investigator: Rolf F. Barth, M.D.

Included are:

1. Report for the overall project and the accomplishments

2. Technical Progress Report I

May 1, 1990 - January 31, 1991

3. Technical Progress Report II

February 1, 1991 - October 31, 1991

cycend as a segarate report

\section{DISCLAIMER}

This ieport was prepared as an account of work sponsored by an agency of the United States Government. Neither the United States Government nor any agency thereof, nor any of their employees, makes any warranty, express or implied, or assumes any legal liability or responsibility for the accuracy, completeness, or usefulness of any information, apparatus, product, or process disclosed, or represents that its use would not infringe privately owned rights. Reference herein to any specific commercial product, process, or service by trade name, trademark, manufacturer, or otherwise does not necessarily constitute or imply its, endorsement, recommendation, or favoring by the United States Government or any agency thereof. The views and opinions of authors expressed herein do not necessarily state or reflect those of the United States Government or any agency thereof.

\section{MASTER}

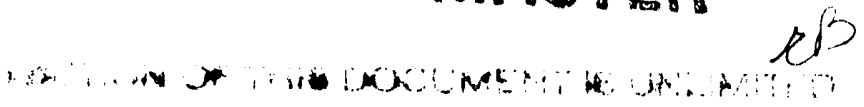




\section{Rationale and Objectives of the Project}

The overall objective of this proposal has been to develop a binary or two-step therapeutic modality for the treatment of primary and metastatic malignant brain tumors. The need for new therapies is based upon the current failure to adequately treat such malignancies by surgery, conventional radiation therapy, and chemotherapy with presently available drugs.

Boron neutron capture therany (BNCT) is one such binary system which offers the potentiality for treating such tumors. It is based on the nuclear reaction that occurs when the stable isotope, boron-10, which constitutes approximately $20 \%$ normal boron,

$$
{ }^{10} \mathrm{~B}+{ }^{1} \mathrm{n}_{\text {th }} \rightarrow\left[{ }^{11} \mathrm{~B}\right] \rightarrow{ }^{4} \mathrm{He}+{ }^{7} \mathrm{Li}+2.31 \mathrm{MeV}
$$

captures a thermal neutron, generating largely high linear energy transfer (LET) particles that are confined to 10 microns approximately 1 cell diameter. The success of this form of therapy is directly dependent upon the delivery of sufficient numbers of thermal neutrons to tumor cells which possess high concentrations of $B-10$. The objective of this project has been to develop:

(1) The chemical methodology needed to synthesize boron-containing compounds with the potential for becoming incorporated into rapidly-dividing malignant brain tumor cells and excluded from normal components of the brain and surrounding tissues.

(2) The biological methods for assessing a compound's potential when the amounts available are in milligram quantities. These have included cell culture and intratumoral injection as a prelude to parenteral administration in tumor-bearing animals.

(3) The analytical methodology for measuring boron in cells and tissue using direct current plasma atomic emission spectroscopy (DCP-AES), alpha track autoradiography and other analytic procedures.

(4) The biochemical and HPLC procedures for evaluating the bas is for compound uptake and persistence.

(5) The procedures required to assess both in vitro and in vivo efficacy of BNCT with appropriate compounds.

\section{Accomplishments-Publications and Presentations}

1. Goodman, J.H., McGregor, J.M., Clendenon, N.R., Gahbauer, R.A., Barth, R.F., Soloway, A.H. and Fairchild, R.G. Inhibition of tumor growth in a glioma model treated with Boron Neutron Capture Therapy. Neurosurgery, $27: 383-388,1990$.

2. Barth, R.F., Soloway, A.H., Fairchild, R.G. Boron neutron capture therapy for cancer. Scientific American 262:100-107, 1990.

3. Barth, R.F., Adams, D.M., Soloway, A.H., Mechetner, E., Alam, F., Anisuzzaman, A. Determination of boron in tissues and cells using direct-current plasma atomic emission spectroscopy. Analytical Chemistry 63:890-893, 1991.

4. Soloway, A.H. Anisuzzaman, A.K.M., Alam, F., Barth, R.F. and Liu, L. The development of carboranyl nucleic acid precursors for use in neutron capture therapy of tumors. Pure \& Appl Chem. 63:411-413, 1991. 
5. Soloway, A.H., Barth, R.F., Alam, F., and Anisuzzaman, A.K.M. Requirements and development of boron compounds for neutron capture therapy of tumors. Nuclear Science Applications, 4:317-324, 1991.

6. Liu, L., Barth, R.F., Soloway, A.H., Anisuzzaman, A.K.M., Tjarks, W., Zhao, $X$. and Morrison, G.H. Cellular uptake and distribution of 2-0-(0carborany l)uridine (CBU) a potential delivery agent for boron neutron capture therapy (BNCT). Proc. Am. Assoc. Cancer Res., 32:321, 1991.

7. Barth, R.F. and Soloway, A.H. Boron neutron capture therapy of cancer: recent progress. Continuing Education Program, 50th Annual meeting of the Japan Neurosurgical Society 1991, pages 1-9.

8. Barth, R.F., Soloway, A.H., Fairchild, R.G. Boron neutron capture therapy a cancer: new developments. Radiation Research: A Twenty Century Perspective ed. Chapman J.D. Dewey W.C. and Whitmore G.F. Academic Press 1992 pp 623-628.

9. Barth, R.F., Soloway, A.H., Adams, D.M., Alam, F. and Anisuzzaman, A.K.M. Determination of boron concentration by means of direct current plasma - atomic emission spectroscopy. in: Progress in Neutron Capture Therapy, Plenum Press, 1992 pp 305-308.

10. Barth, R.F., Soloway, A.H., Adams, D.M. and Alam, F. Delivery of boron10 for neutron capture therapy by means of monocional antibody starburst dendrimer immunoconjugates. in: Progress in Neutron Capture Therapy. Plenum Press, 1992 pp 265-268.

11. Soloway, A.H., Anisuzzaman, A.K.M., Liu, L., Barth, R.F., Alam, F. and Tjarks, W. Carboranyl precursors of nucleic acids-potential DNA probes for BNCT. in: Progress in Neutron Capture Therapy. Plenum Press, 1992 pp 207-210.

12. Matalka, K.Z., Bailey, M.Q., Barth, R.F., Staubus, A.E., Adams, D.M., Soloway, A.H., James, S.M. and Goodman, J.H. A rat model for the treatment of melanoma metastatic to the brain by means of neutron capture therapy. in: Progress in Neutron Capture Therapy. Plenum Press, 1992, pp 429-434.

13. Woolard, J.E., Jiang, Y., Curran, J.F., Blue, T.E., and Barth, R.F. Determination of boron concentrations in tissues by means of alpha autoradiography. in: Progress in Neutron Capture Therapy, Plenum Press, 1992, pp 317-320.

14. Wilson, J.G., Anisuzzaman, A.K.M., Alam, F. and Soloway, A.H. Development of carborane synthons: synthesis and chemistry of aminoalkylcarboranes. Inorg. Chem. 31:1955-1958, 1992.

15. Tjarks, W., Anisuzzaman, A.K.M. , Liu, L. Soloway, A.H., Barth, R.F., Perkins, D.J. and Adams, D.M. Synthes is and in vitro fvaluation of boronated uridine and glucose derivatives for boron neutron capture therapy. J. Med. Chem., 35:1628-1633, 1991.

16. Barth, R.F., Soloway, A.H., Fairchild, R.G. and Brugger, R.M. Boron neutron capture therapy of cancer: present realities and future prospects. Cancer, 70:2995-3007, 1992. 
17. Nishihara, K., Barth, R.F., Liu, L., Tjarks, W., Soloway,A.H., Staubus, A.E., Rotaru, J., Adains, D.M., Bendayan, M. and Kassis, A. Direct intratumoral injection of $2^{\prime}-0$-(0-carboran-1-ylmethyl) uridine (CBU-2'), a potential delivery agent for boron neutron capture therapy (BNCT). Proc. Am. Assoc. Cancer Res., 33:502, 1992.

18. Liu, L., Barth, R.F., Tjarks, W., Soloway, A.H., Ives, D.H. and Bendayan, M. Cellular and biochemical studies on 2'-0-(0-carboran-1ylmethyl)uridine (CBU-2'), a delivery agent for boron neutron capture therapy (BNCT). Proc. Am. Assoc. Cancer Res., 33:503, 1992.

19. Tjarks, W., Anisuzzaman, A.K.M. and Soloway, A.H. Synthes is of 1,3-di0-acetyl-5-0-benzoyl-2-0-)0-carboran-1-ylmethyl)-D-ribofuranose. A general precursor for the preparation of carborare-containing nucleosides for boron neutron capture therapy. Nucleosides and Nucleotides, in press.

20. Soloway, A.H., Barth, R.F., Liu, L., Tjarks, W., Wyzlic, I.M. and Anisuzzaman, A.K.M. Approaches to the design and evaluation of compounds for BNCT in "Toward Clinical Trials of Glioma with BNCT" edited D. Gabel, in press, Pergamon Press.

21. Wyzlic, I.M. and Soloway, A.H. A general convenient way to carboranecontaining amino acids for boron neutron capture therapy. Tetrahedron Letters, in press to be published in 1992.

22. Wyzlic, I.M., Soloway, A.H., Barth, R.F. and Rotaru, J. Synthesis and evaluation of carborane-containing amino acids for boron neutron capture therapy. Fifth International Symposium on Neutron Capture Therapy for Cancer September 13-17, 1992, Columbus, Ohio, page 5.

23. Tjarks, W., Anisuzzaman, A.K.M., Soloway, A.H., Liu, L. and Barth, R.F. Synthesis of carborane-containing nucleosides, nucleotides, and carbohydrates for BNCT. Fifth International Symposium on Neutron Capture Therapy for Cancer. September 13-17, 1992, page 11.

24. Soloway, A.H. and Barth, R.F. Boron neutron capture therapy: a binary system for the treatment of cancer. "Challenges and Controversies in Cancer Research" an international cancer conference September 9-12, 1992, Columbus, Ohio, page 49. 


\section{1) Chemical Aims and Syntheses}

The objectives were to design and synthesize boron-containing nucleosides, amino acids and CNS depressants that would have selectivity for brain tumor cells, be capable of crossing both the blood-brain barrier (BBB) and the tumor cell membrane and become trapped within the cell. Ideally the compounds should either be incorporated into DNA or in close proximity to such structures. The initial goal was to develop the chemical methodology for synthesizing carborane-containing nucleosides, amino acids and CNS depressants and subsequently to prepare chemical nucleotides from the corresponding nucleosides.

The methodology and the desired target compounds in the area of carboranyl nucleosides has been achieved. These have been accomplished starting with the preformed nucleoside. (See Scheme I and II in the Appendix) In addition, we have synthesized, through an eight step sequence, a carboranylribose which has been inserted into a silylated uridine with the subsequent formation of $2^{\prime}-0-(0-$ carboran-1-ylmethyl)uridine (CBU-2'). The synthes is of this same compound is shown in Scheme I (See Scheme III and IV). This carboranylribose now offers the potential for synthesizing analogues of the naturally-occurring nucleosides related to adenine, quanine, cytosine and thymine.

In addition we have succeeded in synthesizing the first carboranecontaining nucleotide. Initially, the p-nitrophenyl derivative of the phosphate function of the $5^{\prime}$-nucleotide, related to $\mathrm{CBU}-2^{\prime}$ was synthesized. However, in attempting to hydrolyze the phosphate-protecting moiety, the nucleotide was completely hydrolyzed. It was necessary to synthesize the nucleotide with a more labile functionality. With this objective, the masked nucleotide using bis(2,2,2-trichloroethy 1) phosphorochloridate has been synthesized. This compound has been hydrolized and the 5'-monophosphate convertied to its sodium salt (Scheme $V$ in Appendix). An HPLC system has been developed for the purification of these carboranyl nucleotides.

A general method for the preparation of carborane-containing amino acids is presented in the paper which is included in the Appendix. This offers the potentiality for synthesizing a variety of boron-containing amino acids. In addition we have developed the methodology for the synthes is of appropriate carborane-containing CNS depressants. Now that the methodology has been developed, appropriate target compounds will be synthesized related to phenobarbital.

\section{2) Analytical}

A major limitation in the in vitro and in vivo screening of boron compounds in glioma cells has been the need for the development of an analytical procedure which could be applied to cells and tissues containing boron compounds that are not isotopically enriched. The development of an analytical procedure using direct current plasma atomic emission spectroscopy (CCP-AES) has met this objective (\#3 in Accomplishments). Cells and tissues in the range of $25-50 \mathrm{mg}$ can be readily analyzed at a level of greater than $0.5 \mu \mathrm{g} \mathrm{B} / \mathrm{sample.}$

\section{3) Biological Studies}

A major limitation in the biological evaluation of new boron compounds has been the fact that initially they are prepared in such small quantities 
(miliigram amounts) that in vivo evaluation is not possible. The development of an in vitro screening procedure that could assess their potential as capture agents for BNCT would offer clear advantages. If the compound demonstrated promise, shown by in vitro uptake and persistence in neoplastic cells, then sufficient amounts could be synthesized for in vivo evaluation. With this objective, compounds have been screened in vitro using rat F98 glioma and murine Bi6 melanoma ce] ls by the following procedure. Tumor cells $\left(2 \times 10^{5}\right)$ were seeded in a $150 \mathrm{~cm}^{2}$ tissue culture flask and incubated in $30 \mathrm{ml}$ of Dulbecco's Modified Eagle Medium (DMEM) supplemented with 10\% Fetal Bovine Serum (FBS). Upon reaching semi-confluerice, the medium was decanted and fresh DMEM/FBS containing varying concentrations of the particular boron compound were added. The boron concentration in the medium ranged from 5.4 $116 \mu \mathrm{g}$ boron $/ \mathrm{ml}$ and was dependent upon the compound's solubility. Following 16 hrs. incubation, the boron-containing medium was then decanted and the cell monolayer was washed with Phosphate- Buffered Saline (PBS, PH 7.4), and the cells were disaggregated by trypsinization. After determining the total number of cells, the suspension was centrifuged and the supernatant discarded. The pellet was solubilized with concentrated sulfuric acid and hydrogen peroxide and their boron uptake determined. Values $<0.5 \mu \mathrm{g} \mathrm{B} / \mathrm{sample}$ approximated a background reading and were considered unmeasurable. To measure the boron concentration jn $\mu \mathrm{g}$ per $\mathrm{g}$ of cells, the number of $\mathrm{F} 98 \mathrm{glioma}$ and B16 melanoma cells per $g\left(10^{9}\right.$ cells) was determined and the number of $\mu \mathrm{g}$ of boron per sample was extrapolated to the amount per $g$ of cells. The cellular uptake of the compounds, as shown below, demonstrate significantly greater incorporation of the closo-carboranes compared with $\mathrm{Na}_{2} \mathrm{~B}_{12} \mathrm{H}_{11} \mathrm{SH}$. This, in part, may be due to the greater lipophilicity of these carborane-containing nucleosides by comparison with the mercapto-polyhedral borane anion.

Comparable results also have been obtained with $B 16$ melanoma and with U87 MG glioma, $3 T 3$ and MDCK fibroblasts.

For compounds taken up by neoplastic cells, it is important to determine their retention times. This has been studied by resuspending cells in boronfree media and incubating them for varying times ranging from 1 to $48 \mathrm{hrs}$. Aliquots of cells then were analyzed for boron content. For the purpose of comparison, CBU-2' was compared with $\mathrm{Na}_{2} \mathrm{~B}_{12} \mathrm{H}_{11} \mathrm{SH}$ in $\mathrm{F98}$ glioma cells. These results are shown in the figure $\# 1$.
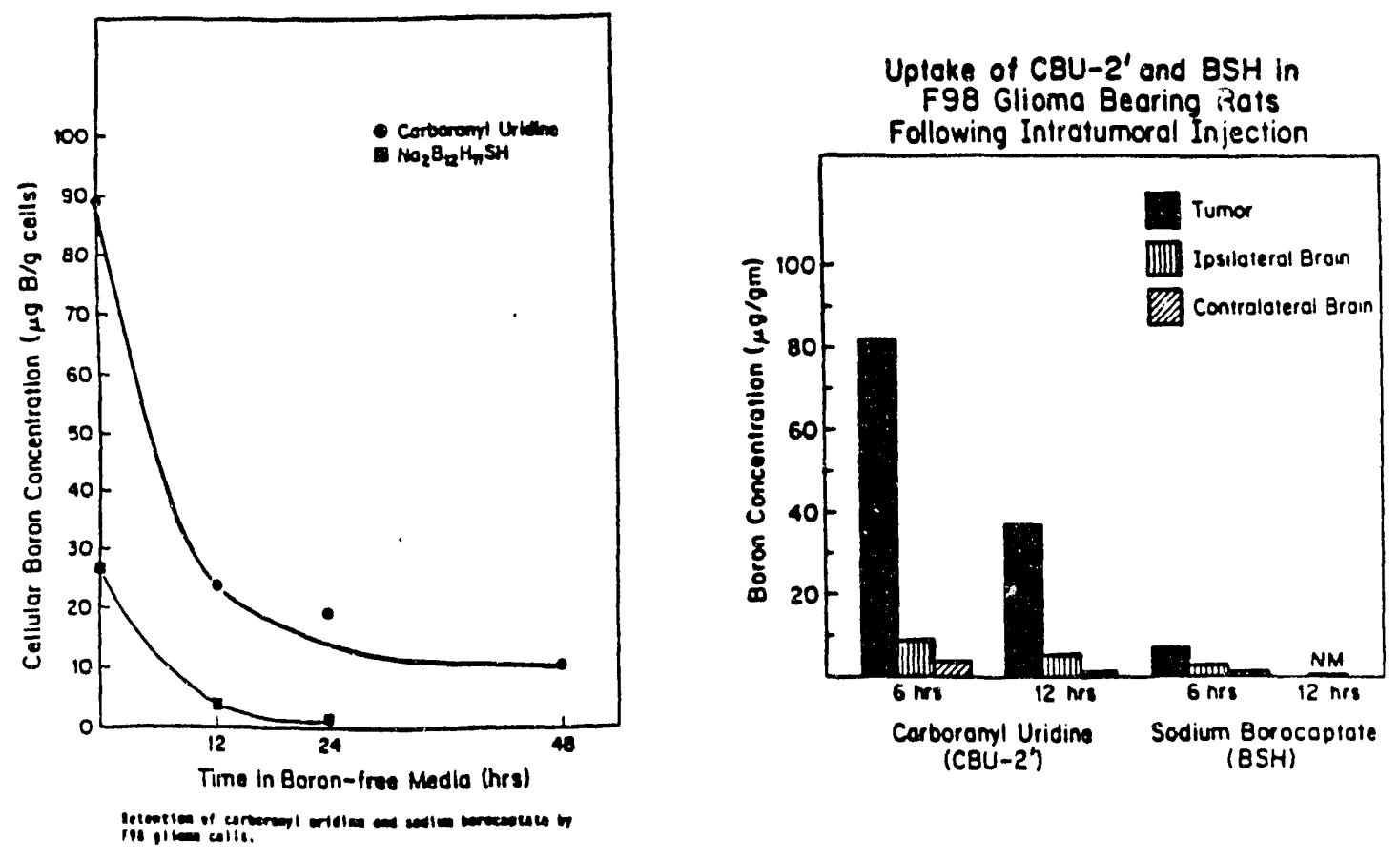


\section{A}

From these data it is apparent that $C B U-2$ ', as determined by its boron content, persisted for appreciable times once it was taken up by F98 glioma cells and this was in marked contrast with $\mathrm{Na}_{2} \mathrm{~B}_{12} \mathrm{H}_{11} \mathrm{SH}$ which rapidly diffused, attaining background levels within $12 \mathrm{hrs}$. The precise physiological/biochemical mechanisms that account for such retention and the importance of the nucleoside moiety on both uptake and retention has yet to be determined. By culturing $F 98$ glioma cells with three metabolic inhibitors: 6[(4-nitrobenzy1)thio]-9-B-D-ribofuranosylpurine (NBMPR) and dipyridamole, two nucleoside membrane transport inhibitors and rotenone, which blocks electron transport, we have demonstrated that these inhibitors do not interfere with the cellular uptake of CBU-2'. Uptake, therefore, was neither energy nor nucleoside transport dependent, but probably was based, at least in part, upon the compound's lipophilicity. Subcellular fractionation studies revealed that $84 \%$ of recoverable boron was in the cytosol, $15 \%$ bound to protein and $1 \%$ in the DNA/RNA fraction. Schinazi (personal communication) has reported to us that similar carboranyl nucleosides are phosphorylated in cell culture to the monophosphate with no evidence of the formation of the di-and triphosphates. This observation could account for the basis of cellular retention but our results, stemming from the isolation of nucleic acid precursors from cell culture, show no nucleotide formation. These results are not surprising, given the ribosidic character of the particular analogue prepared.

In collaboration with Professor George Morrison at Cornell University, cellular uptake has also been studied by means of ion microscopy (\#6 Accomplishments). F98 glioma cells were grown on polished silicon waffers and incubated with $50 \mu \mathrm{g}$ of $\mathrm{CBU}-2^{\prime} / \mathrm{ml}$ for 2,6 and $16 \mathrm{hrs}$ before being freezefractured under liquid $\mathrm{N}_{2}$. With this methodology, it was observed with CBU$2^{\prime}$ : (1) the boron was mainly concentrated and evenly distributed throughout the cytoplasm; and (2) the cytoplasm and nuclei had higher concentrations than with $\mathrm{Na}_{2} \mathrm{~B}_{12} \mathrm{H}_{11} \mathrm{SH}$.

This uptake and cellular persistence by $\mathrm{F} 98 \mathrm{glioma}$ cells prompted the intratumoral injection of $\mathrm{CBU}-2^{\prime}$ and $\mathrm{BSH}$ in glioma-bearing rats, as a first approach to in vive deliyery of these compounds. This technique has been used by Kassis with $\left.\overline{5-[23} \mathrm{I} /{ }^{125} \mathrm{I}\right]$ iodo-2'-deoxyuridine and is based upon the fact that a cell-cycle dependent agent will only be taken up by dividing cells during a period of DNA synthesis. If direct intratumoral injection of a compound results in selective uptake and retention, then systemic delivery by either intravenous or intracarotid injection would be the next step. Fischer 344 rats were implanted stereotactically with 10,000 F98 glioma cells into the right caudate nucleus. This technique has resulted in a $100 \%$ take of tumor in injected rats. Fourteen to 21 days following implanatation, brain tumor bearing rats were injected intracerebrally with $10 \mu 1$ of either $\mathrm{CBU}-2^{\prime}$ or $\mathrm{BSH}$ in a solution containing $34 \%$ hydroxypropy 1 -cyclodextrin and $1.2 \%$ agarose using the same stereotactic coordinates that had been used to implant the tumor. Animals were killed at 3,6, 12 and 24 hours following injection of the compound, the tumors dissected, and the tumor, the remaining ipsilateral and contralateral cerebral hemispheres were analyzed for boron content. Control experiments were carried out using the identical procedure except that the compounds were injected into the brains of non-tumor bearing rats. Some of the results of these studies are summarized in Figure \#2 above and indicate that there was significant uptake of CBU-2' at 6 and 12 hours ( 82 and $37 \mu \mathrm{g}$ $\mathrm{B} / \mathrm{gm}$ respectively) in the gliomas compared to BSH (7.8 and non-measurable). The amount of boron present in the ipsilateral hemispheres at 6 hours was 8.5 $\mu \mathrm{g} \mathrm{B} / \mathrm{gm}$ for CBU-2' and $2.5 \mu \mathrm{g} \mathrm{B} / \mathrm{gm}$ for $\mathrm{BSH}$ and at 12 hours $5.8 \mu \mathrm{g} \mathrm{B} / \mathrm{gm}$ and non-measurable respectively. 
There was considerable variability in the amount of boron detected at the site of injection irrespective of whether the CBU-2' or BSH was injected into tumor-bearing or non-tumor bearing rats. With CBU-2', boron levels decreased rapidly between 3 and 24 hours at which time the mean values ranged from 3.6 to $11 \mu \mathrm{g} \mathrm{B} / \mathrm{gm}$ for tumor, 1.7 to $6.8 \mu \mathrm{g} \mathrm{B} / \mathrm{gm}$ for normal brain from the ipsilateral hemisphere, and non-measurable (NM) to $0.8 \mu \mathrm{g} \mathrm{B/g}$ for normal brain from the contralateral hemisphere. In order to determine what effects, if any, agarose had on the diffusion of the CBU-2', a comparison 4 !as made with CBU-2' that had been dissolved in Hanks' Balanced Salt Solution (HBSS) and Bcyclodextrin. These results clearly showed that agarose decreased the rate of diffusion of CBU-2' from the injection site and the ipsilateral cerebral hemisphere, but had no effect on the amounts detected in the contralateral hemisphere. BSH cleared more rapidly from the injection site than $\mathrm{CBU}-2^{\prime}$ and was non-measurable at all sites that were sampled by $24 \mathrm{hrs}$.

The in vitro and in vivo data that we have accumulated at this point suggest that $\overline{\mathrm{CBU}-2}$ ' may not be selective enough to target brain tumors. Before any final conclusions are made, however, it will be essential to carryout distribution studies following systemic rather than intratumoral injection of the compound. 
Appendix 


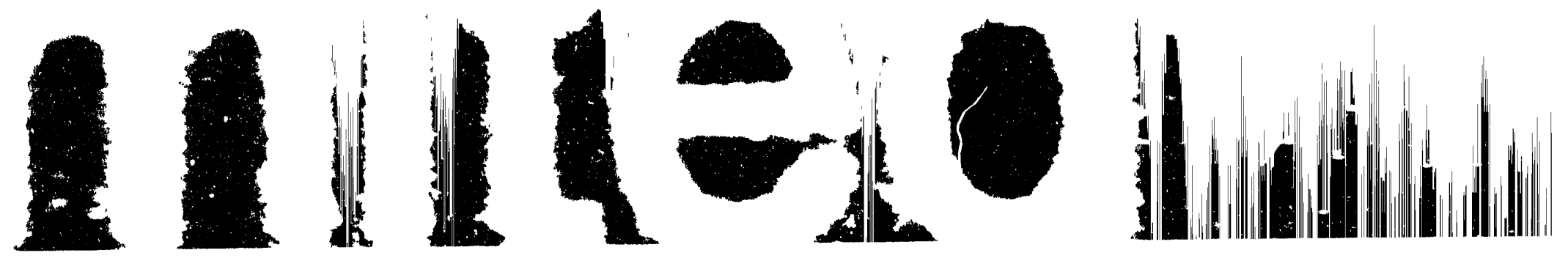

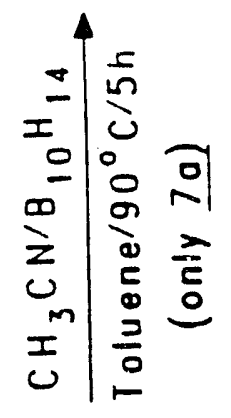
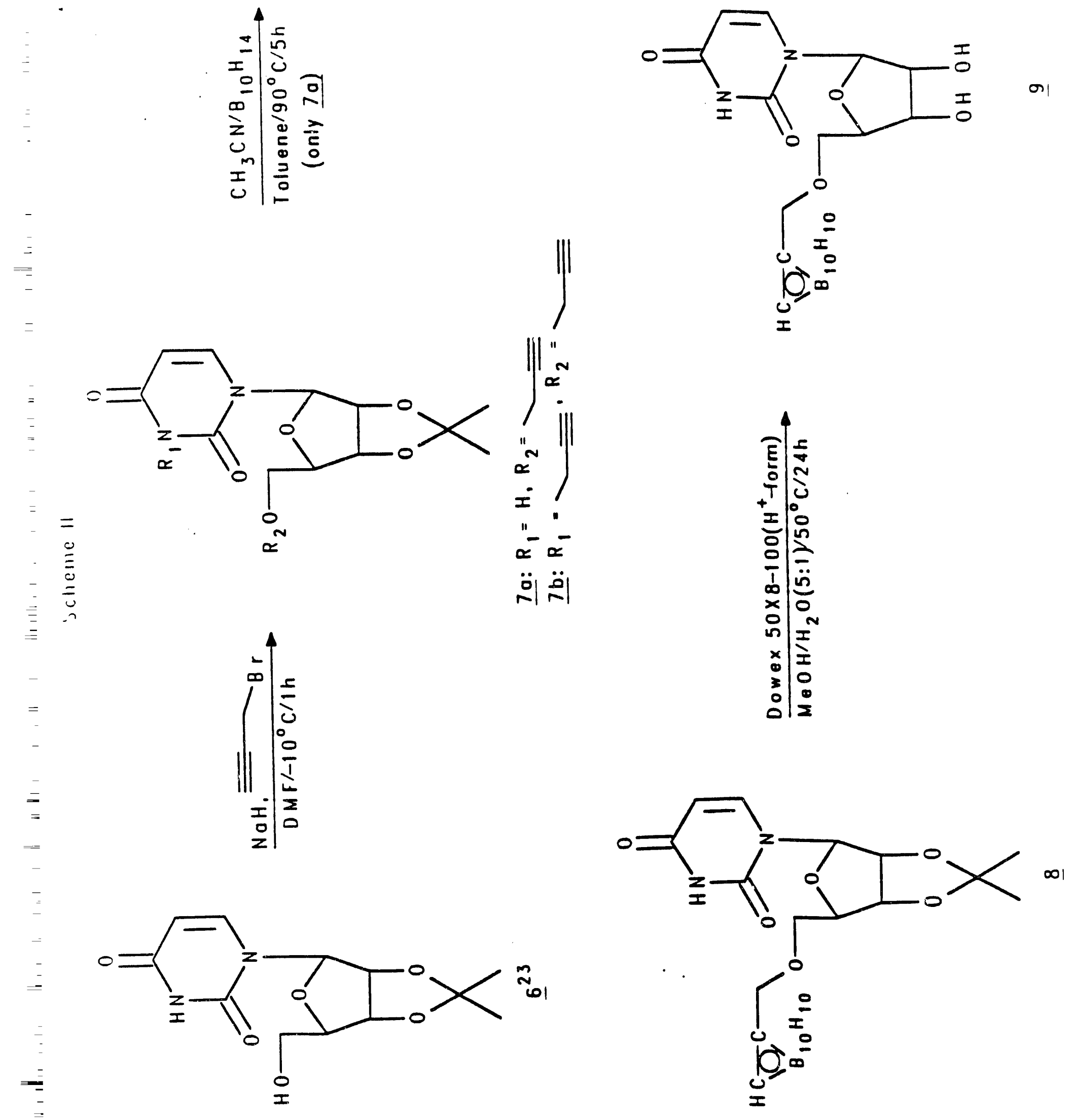
Sctume III
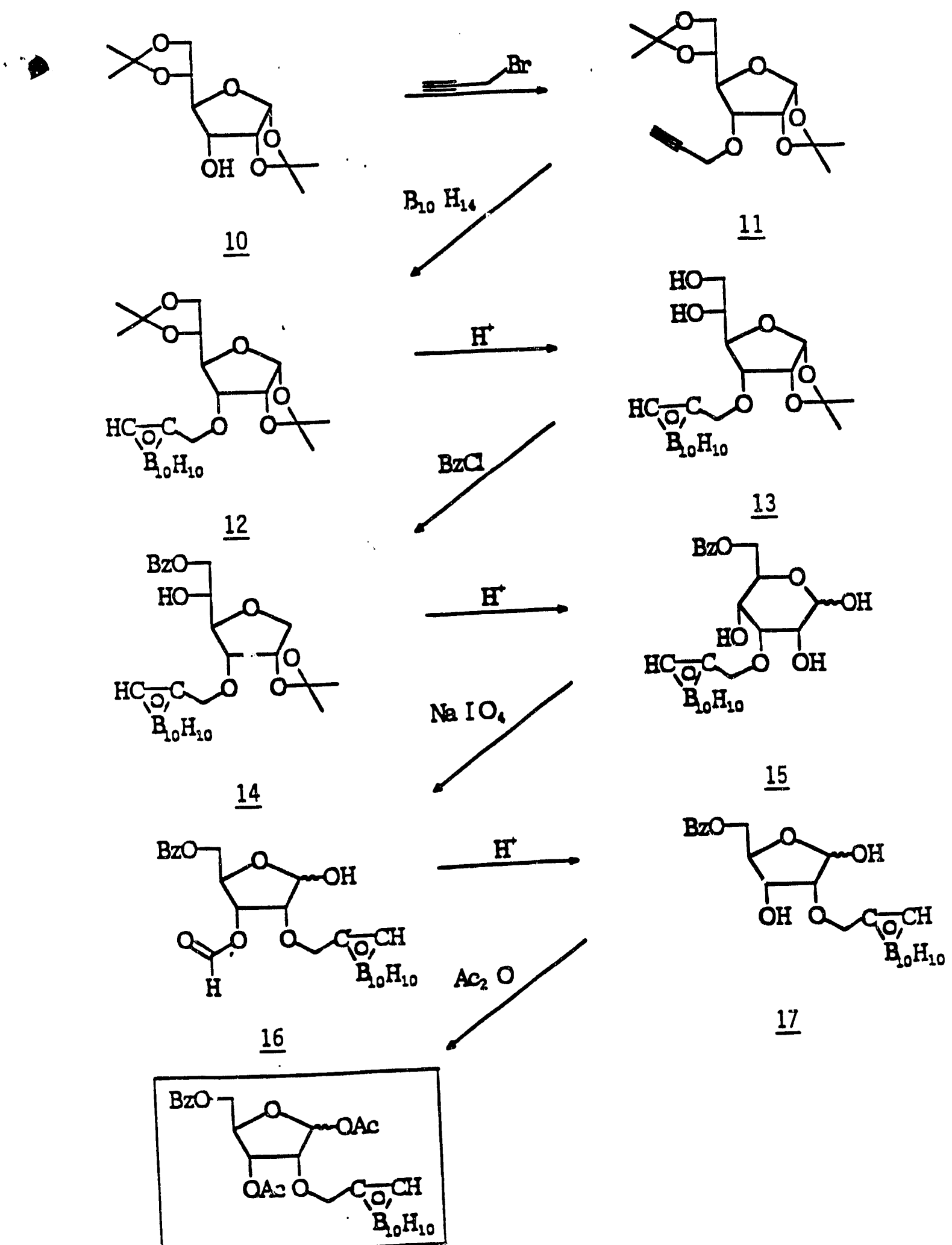

17 


\section{Scheme It}

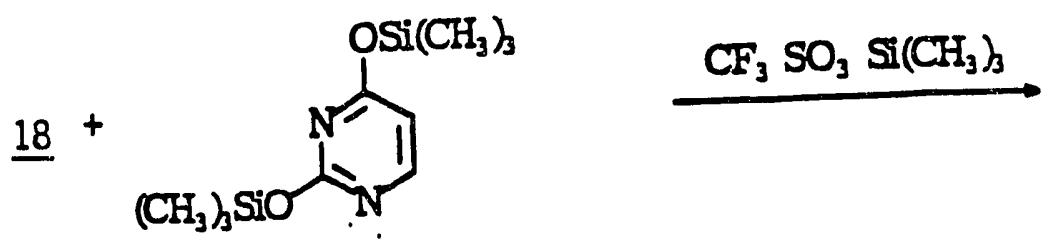

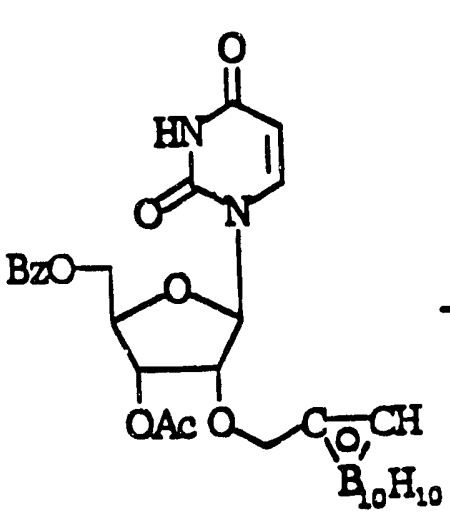

$\underline{19}$

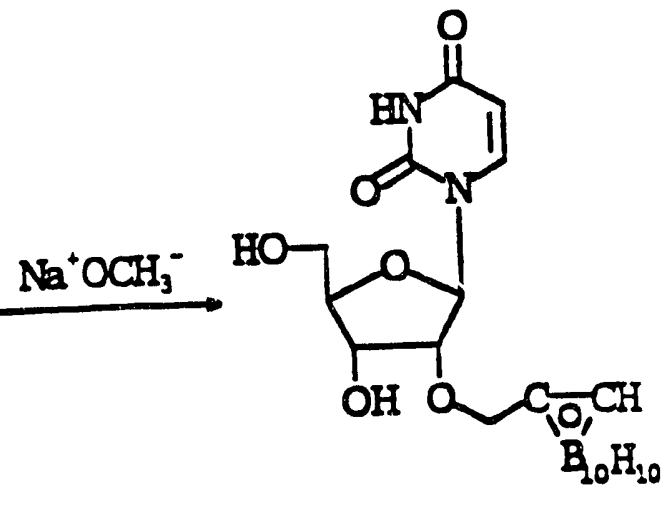

20 
Scheme V

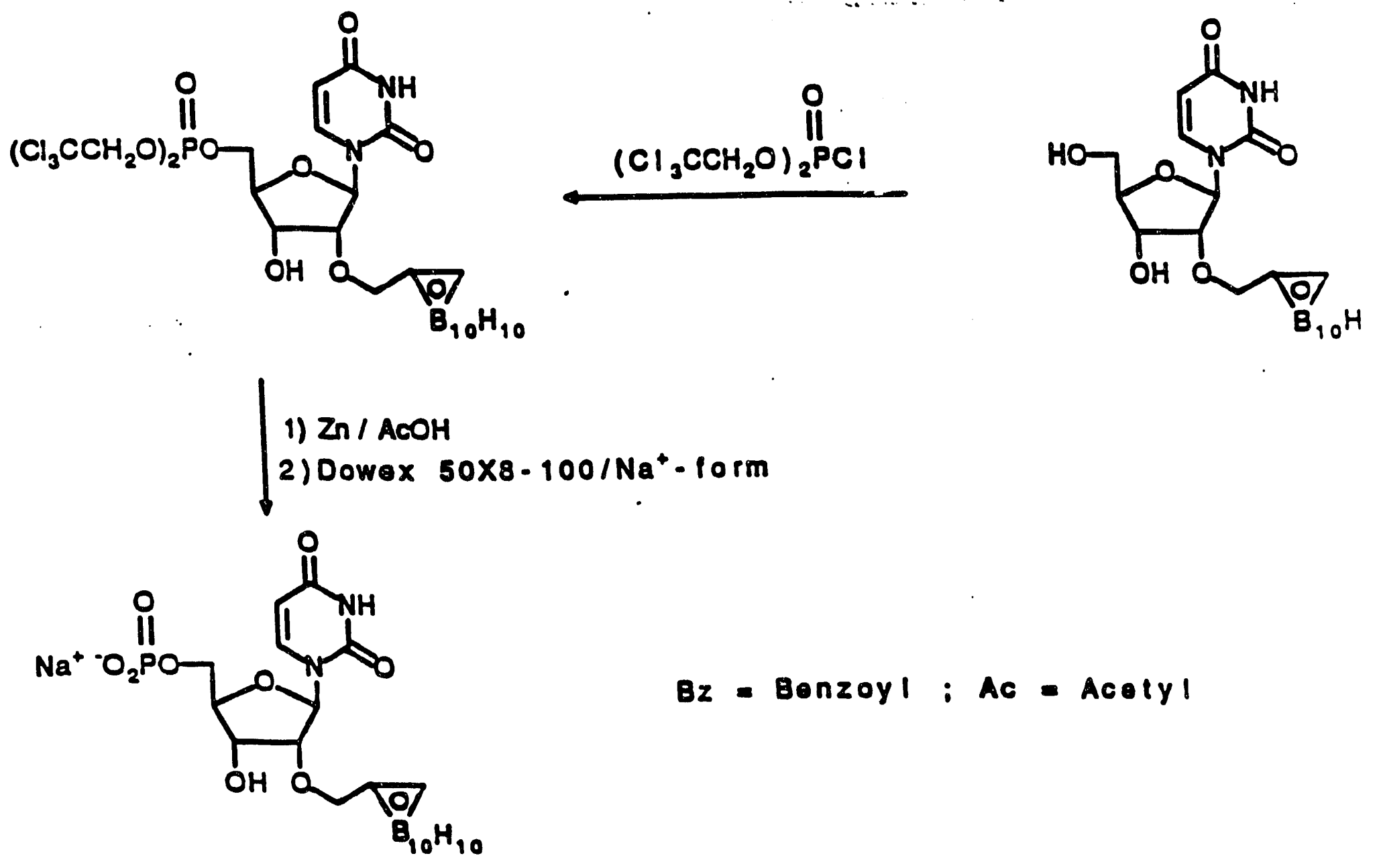




\title{
A General, Convenient Way to Carborane-Containing Amino Acids for Boron Neutron Capture Therapy
}

\author{
Iwona M. Wyzlic* and Albert H. Soloway
}

College of Pharmacy, The Ohio State University, 500 West 12th Avenue, Columbus, OH 43210, USA

\begin{abstract}
A general, convenient procedure for the synthesis of carborane-containing amino acids in good yield has been developed. The synthesis of 0 -carboranylalanine 1, O-(0-carboran-1-ylmethyl)-tyrosine 2 and p-(o-carboran-1yl)-phenylalanine 3 is reported.
\end{abstract}

$\mathrm{p}$-Boronophenylalanine ( $\mathrm{p}-\mathrm{BPA})^{1}$ is the first boron-containing amino acid that has been used in treatment of melanoma by means of Boron Neutron Capture Therapy $(B N C T)^{2}$. However, there is only a single boron atom in this amino acid and the structure appears to be metabolically unstable. This is rationale for the synthesis of carborane-containing analogues (10 boron atoms) of aromatic amino acids, which from metabolic studies with related compounds, might be highly resistant to oxidative changes.

In this letter, we describe a new, convenient procedure to previously synthesized $o$ carboranylalanine $1^{3}$ (70\% total yield) and two new boron-containing amino acids, O-(o-carboran1-ylmethyl)-tyrosine 2 (77\% total yield) and p-(o-carboran-1-yl)-phenylalanine 3 (71\% total yield).

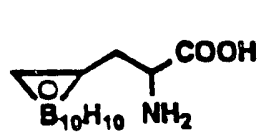

1

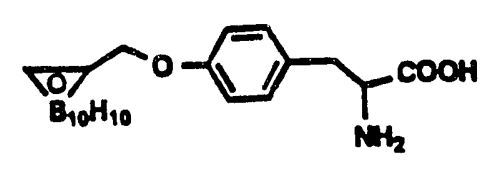

2

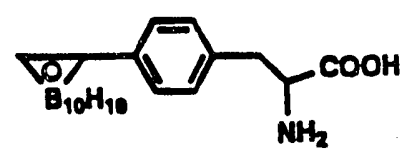

3

$o$-Carboranylalanine 1 is a potential analogue of phenylalanine and might be useful for BNCT. The dimensions of the cage are only slightly larger than space occupied by a benzene ring rotating about its $\mathrm{C}(1)-\mathrm{C}(4)$ axis, and its two carbon atoms participate in the delocalized bonding ${ }^{3}$.

The synthesis of 1 involves a phase transfer alkylation 4 of commercially available $\mathrm{N}$ (diphenylmethylene)aminoacetonitrile, 4 , with propargyl bromide to yield monoalkylated product 5 . Boronation of 5 with a decaborane-acetonitrile complex followed by the partial hydrolysis of the alkylated Schiff's base, 6 , with $6 \mathrm{~N} \mathrm{HCl}$ affords the aminonitrile 7 . In order to hydrolyze the cyano function stronger acidic conditions $\left(70 \% \mathrm{H}_{2} \mathrm{SO}_{4}, 95^{\circ} \mathrm{C}, 24 \mathrm{~h}\right)$ are required to obtain $o$-carboranylalanine, 1 . 
$\mathrm{H}=\mathrm{CH}_{2} \mathrm{Br}+\mathrm{N}_{\mathrm{N}}^{\mathrm{C}}$

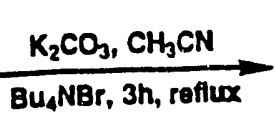

Bu,NBr, 3h, raflux<smiles>C#CCC(C)N=C(c1ccccc1)c1ccccc1</smiles>

$\mathbf{5}$
$\frac{\mathrm{B}_{10} \mathrm{H}_{12}\left(\mathrm{CH}_{3} \mathrm{CN}\right)_{2}}{\text { toluene, } 90^{\circ} \mathrm{C}, 4 \mathrm{~h}}$

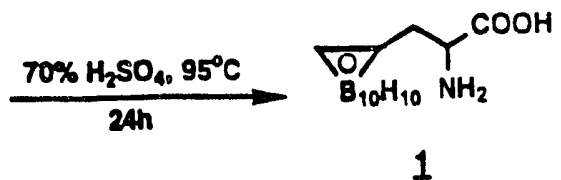

6

6N HCI, RT, 18h

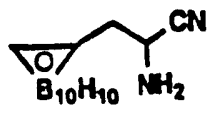

7

The same procedure has also been applied to the synthesis of 0 -(o-carboran-1-ylmethyl)tyrosine, 2 and p-(o-carboran-1-yl)-phenylalanine, 3. The corresponding carborane-containing psubstituted-benzyl bromides have been used in alkylating 4 , followed by acid hydrolysis to produce the corresponding amino acids. This procedure yields a racemic mixture of the carboranecontaining amino acids and these are now being separated into their enantiomers for biological evaluation.

In summary, a practical method for the synthesis of carborane-containing amino acids, has been reported. This procedure can be used for the synthesis of the other boron-containing amino acids that might be potentially useful in treatment of cancer by means of BNCT.

Acknowledgement: This research has been supported by the U.S. Department of Energy grant DE-FG02-90ER60972 and contract DE-AC02-76CH000616 and the National Cancer Institute of the U.S. Public Health Service RO1 CA 53896.

\section{References and Notes:}

1. Snyder, H.R.; Reedy, AJ.; Lennarz, Wm.J. J. Am. Chem. Soc. 1958, 80, 835-838.

2. a) Barth, R.F.; Soloway A.H.; Fairchild, R.G. Cancer Res. 1990, 50, 1061-1070; b) Coderre, J.A.; Kalef-Ezra. J.A.; Fairchild, R.G.; Micca, P.L.; Reinstein. L.E.; Glass, J.D. Cancer Res. 1988, 48, 6313-6316; c) Mishima, Y.; Ichihashi, M.: Bui, M.: Sasumu H.; Ueda, M.; Honda, C: Susuli, T. J. Iavest. Dermatol. 1989,92 (Suppl.), 3215-3255; d) Mishima, Y.; Ichihashi, M.: Tsui, M.; Hatta, S.; Ueda, M.; Honda, C.; Susuki. T. Lancet. 1989. 2. 388-389.

3. a) Leukart, O.; Caviezeh, M.: Eberie, A.; Escher, E.: Tun-Kyi, A.: Schwyzer, R. Helv. Chim. Acta 197 6, 59. 2184; b) Sjoberg, S. Workshop on Chemistry and Biology on BNCT, 1991 , Uppsala; c) Radel, P.; Kahl. S. BUSA III. 1992. Pullman. a) O'Donnell, M.J.; Eckrich Chem. $1982,47,2663$. o-Carboranylalanine (1): m.p. $205-208^{\circ} \mathrm{C}$ (dec.); $\left.\mathrm{MS}_{(\mathrm{FAB}}^{+}, 3-\mathrm{NBA}\right) 232(\mathrm{M}+\mathrm{H})^{+}$; Anal. Calcd for
$\mathrm{C}_{5} \mathrm{H}_{17} \mathrm{NO}_{2} \mathrm{~B}_{10}$ : C. 25.96; H. 7.41: N, 6.06; B. 46.77. Found: C. 25.78; H, 7.30; N, 5.99; B, 46.50. ' $\mathrm{H}$ NMR $\left(\mathrm{MOOH}-\mathrm{d}_{4}\right)$ 8: 1.1-3.4 (br, m, 10H, B-H); $2.72,3.12\left(\mathrm{~d}\right.$ of $\left.\mathrm{AB}_{\mathrm{q}}, 2 \mathrm{H}, \mathrm{CH}_{2}-\mathrm{J}_{\mathrm{AB}}=16.0, \mathrm{~J}_{\mathrm{gx}}=4.8, \mathrm{~J}_{\mathrm{AX}}=6.3\right) ; 3.94$ (h) $\left.1 \mathrm{H}_{\mathrm{X}},-\mathrm{CH}-\mathrm{J}=5.2\right) ; 4.81$ (br, s, IH. $\mathrm{C}_{\text {earbonane }} \cdot \mathrm{H}$ ). O-(o-Carboran-1-ylmethyl)-tyrosine (2): m.p. 196-1970 C; $M S\left(\mathrm{FAB}^{+}, 3-\mathrm{NBA}\right) 338(\mathrm{M}+\mathrm{H})^{+}$; Anal. Calcd for $\mathrm{C}_{12} \mathrm{H}_{23} \mathrm{~B}_{10} \mathrm{NO}_{3}$ : C. 42.71; H. 6.87; N, 4.15; B, 32.04. Found: C. 42.45; $\mathrm{H}, 6.77 ; \mathrm{N}, 4.00 ; \mathrm{B}, 31.91$.

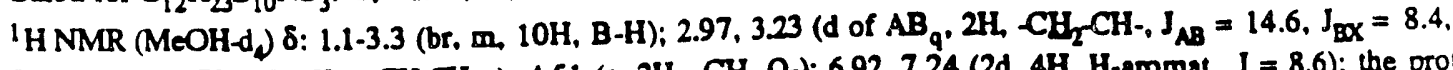

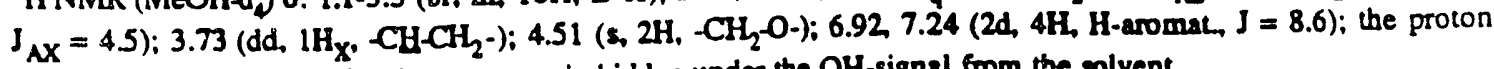
bonded to carbon atom of carborane cage is tridden under the $\mathrm{OH}$-signal from the solvent . p-(o-Carboran-1-yl)-phenglalanine (3): m.p. 200-201 ${ }^{\circ} \mathrm{C}$; $\mathrm{MS}\left(\mathrm{FAB}^{+}, 3-\mathrm{NBA}\right) 308(\mathrm{M}+\mathrm{H})^{+}$: Anal. Calcd for $\mathrm{C}_{11} \mathrm{H}_{21} \mathrm{NO}_{2} \mathrm{~B}_{10}$ : $\mathrm{C}, 42.98 ; \mathrm{H}, 6.89 ; \mathrm{N}, 4.56 ; \mathrm{B}, 35.17$. Found: C, 42.68; H. 6.67; N, 4.41; B, 35.20. ' $\mathrm{H}$ $\operatorname{NMR}\left(\mathrm{MeOH}-\mathrm{d}_{4}\right)$ 8: 1.2-3.3 (br, m, 10H.B-H); 3.04, 3.27 (d of $\mathrm{ABq}_{4} 2 \mathrm{H}_{4}, \mathrm{CH}_{2}, \mathrm{~J}_{\mathrm{Ag}}=14.5, \mathrm{~J}_{\mathrm{BX}}=8.3, \mathrm{~J}_{\mathrm{AX}}=4.7$ );

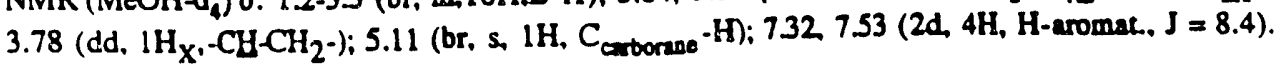




\section{Technical Progress Report I}

Title:

Contract No.:

Project Period:

Institution:

Principal Investigator:

Co-Principal Investigator: Rolf F. Barth, M.D.
Synthesis and Evaluation of Boron Compounds for Neutron Capture Therapy of Malignant Bri in Tumors

Department of Energy DE-FG02-90ER60972

May 1, 1990 - January 31, 1991

The Ohio State University

Albert H. Soloway, Ph.D. 
Scientific Programs and Current Status

1. Synthesis of Chemical Structures for Malignant Brain Tumors a. Preparation of Boron-Containing Derivatives of Lipophilic

The observation that anticonvulsants and CNS depressants readily enter the brain and in some cases achieve glioma:brain differential concentrations brain and in some cases achieve glioma:brain diffective agents for delivering
of $4: 1$ potentially make these compounds attrach, we have embarked on the
boron to brain tumors. As an initial approach, we synthesis of the following barbiturates:

$$
R_{1}=R_{2}=-C_{2}-C C_{R_{1} H_{10}}^{C H} \text {. }
$$

The appropriately substituted propargylmalonic esters have been synthesized and efforts are now underway to prepare the corresponding acetylenic barbiturates. Such structures would ultimately be converted to the corresponding carboranyl barbiturates for evaluation in glioma cell cultures and if appropriate in tumor-bearing animals.

b. Carboranyl Precursors of Nucleic Acids and Related Structures It has been determined that the biological effectiveness of BNCT will be maximized if the capture reaction were to occur in the cell nucleus in comparison with the cytoplasm, on cell membrane or in spaces. This has been the basis for the ongoing synthesis of boron compounds which are chemically similar to the building blocks of the nucleic acids. We have succeeded in synthesizing the $2^{\prime}$ position of the carbohydrate nucleoside with the boron cluster on the 2 portion of the compound, 2 of the carborane moiety on the carmational and electronic changes in the done so as to minimize any confor The following compounds have now been base portion of the nucleoside. The feing evaluated biologically as is synthesized and are in the process 

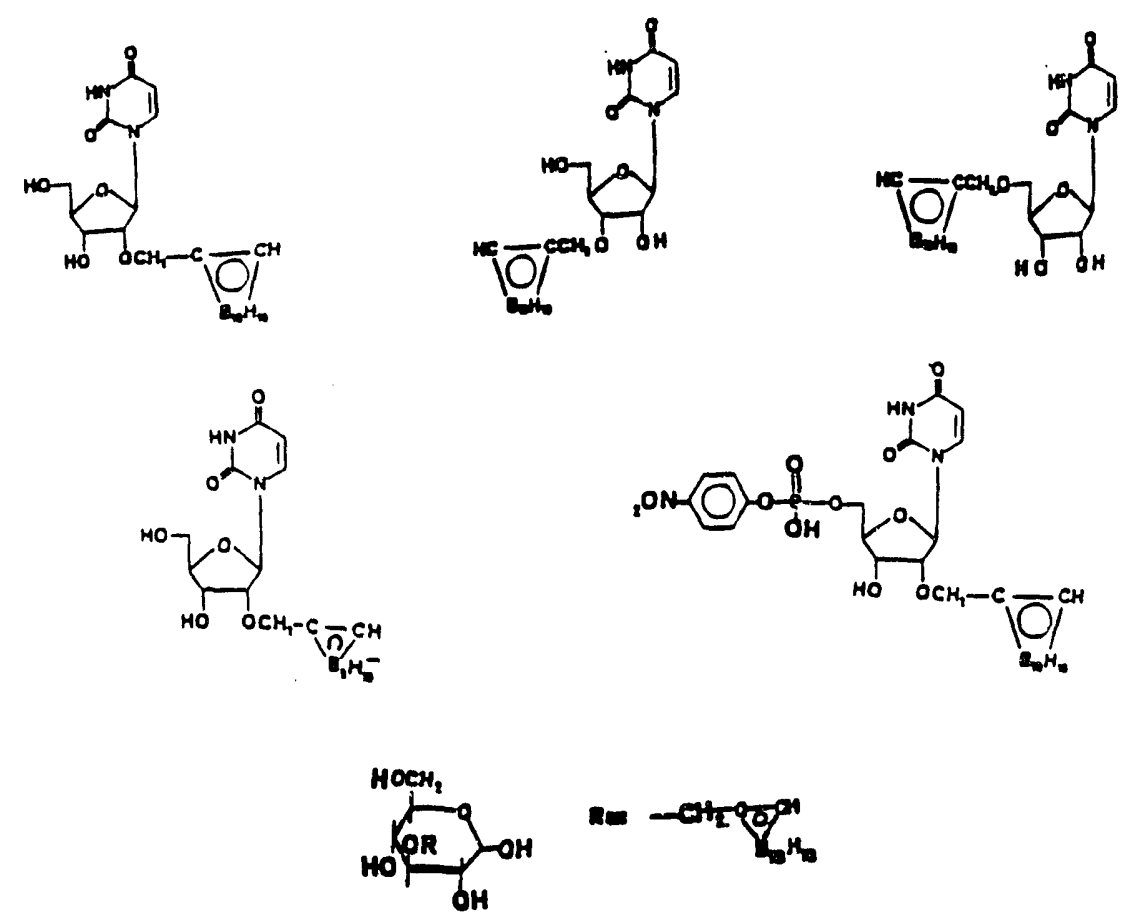

\section{c. Carboranyl Amino Acids}

In view of the brain's facilitated transport system for large and neutral amino acids, preliminary efforts are now underway to prepare a carboranyl analogue of tyrosine. In order to achieve this objective, masked derivatives of the amino and carboxyl groups of tyrosine are needed into which the propargyl group may be attached on the phenolic function. To date, we have not prepared this needed intermediate in the synthesis of the desired target compound but our efforts have only begun.

\section{Cellular Uptake and Persistence Studies}

Cellular uptake and persistence studies have been carried out with F98 rat glioma cells. The objective has been to develop boron compounds which would not just achieve a transient differential between glioma and normal brain and blood but compounds which would persist. In order to make such an assessment, comparisons have been made between boric acid, $\mathrm{Na}_{2} \mathrm{~B}_{12} \mathrm{H}_{11} \mathrm{SH}$ and $2^{\prime}-0-(0-c a r b o r a n y 1-1-m e t h y 1)$ uridine (Figure \#1). 10 Tumor cet s were $^{2}$ cultured in the presence of the various compounds for $16 \mathrm{hrs}$ and after washing they were analyzed for boron content. 


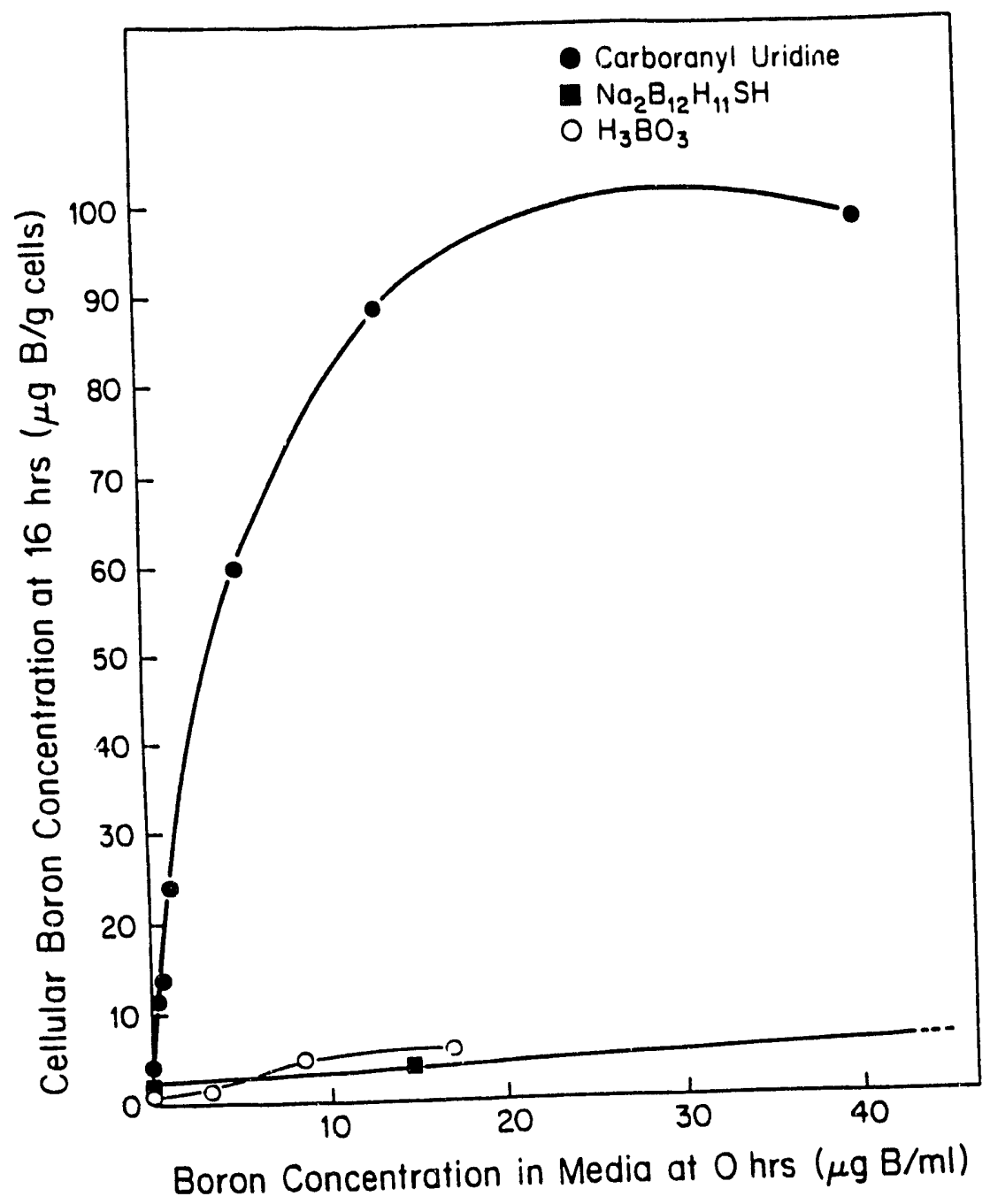

fig. 1. Uptake of carboranyl uridine sodium borocaptate and boric acid by F98 gifoma cells.

These results have led to a comparison of $\mathrm{Na}_{2} \mathrm{~B}_{12} \mathrm{H}_{11} \mathrm{SH}$ and the carboranyluridine for persistence in these gTioma cells. Cultures of these cells, after exposure to the boron compounds, were then incubated in boron-free media for an additional 12, 24 or 48 hours and aliquots of these cells analyzed for boron content. The data of these in vitro studies are shown in Table 1. 


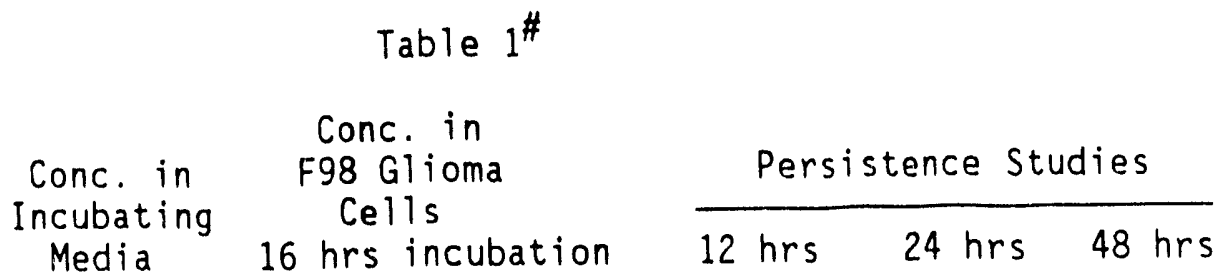

\begin{tabular}{lrrrrr}
\hline $\mathrm{Na}_{2} \mathrm{~B}_{12} \mathrm{H}_{11} \mathrm{SH}$ & 14.6 & 4.3 & $3.1 \dagger$ & $.4 \dagger$ & * \\
$\mathrm{Na}_{2} \mathrm{~B}_{12} \mathrm{H}_{11} \mathrm{SH}$ & 58.0 & 7.2 & $2.8 \dagger$ & $.8 \dagger$ & $*$ \\
$\mathrm{Na}_{2} \mathrm{~B}_{12} \mathrm{H}_{11} \mathrm{SH}$ & 116.0 & 26.7 & $3.4 \dagger$ & $1.8 \dagger$ & $*$ \\
Carboranyl Uridine & 13.5 & 88.9 & 23.9 & 19.3 & 10.5 \\
Carboranyl Uridine & 40.5 & 98.2 & 24.1 & 22.0 & 12.7 \\
\hline
\end{tabular}

\#11 values are in $\mu \mathrm{g}$ boron/g or $\mathrm{ml}$.

* Not measured.

$\dagger$ These approximate the blank value for cells, the average DCP reading being 1.3 (range .4-3.0).

The results are both striking and replicative and demonstrate a significant degree of persistence in the glioma cells for the carboranyl uridine. Additionally, fractionation studies were carried out to determine where in the cell this boron compound was localized.

Preliminary indications are that approximately $30 \%$ is associated with the cell nucleus. It remains, however, to be determined if the carboranyluridine is phosphorylated and incorporated into DNA? Studies to measure the compound's in vivo tumor-localizing properties will be initiated using sustained release pellets for continuous administration.

\section{Summary of Project $1991 / 1992$}

The objectives of this proposal have not changed, namely the synthesis and evaluation of brain tumor-localizing boron compounds which would not only achieve suitable concentration differentials but a high degree of persistence. We have now developed an appropriate in vitro cell culture system for compound evaluation and an analytical method for measuring boron content in cells by atomic emission spectroscopy. It is essential that we translate these in vitro results into a suitable tumor-bearing animal model and determine the appropriate dosing regimen in order to attain high persistence differential in vivo between brain tumor and contiguous normal structures. Further progress is also anticipated in the area of compound development with the recruitment of an additional postdoctoral fellow to join Dr. Werner Tjarks who came here in July 1990. Dr. Wyzlic should join us in April 1991. 

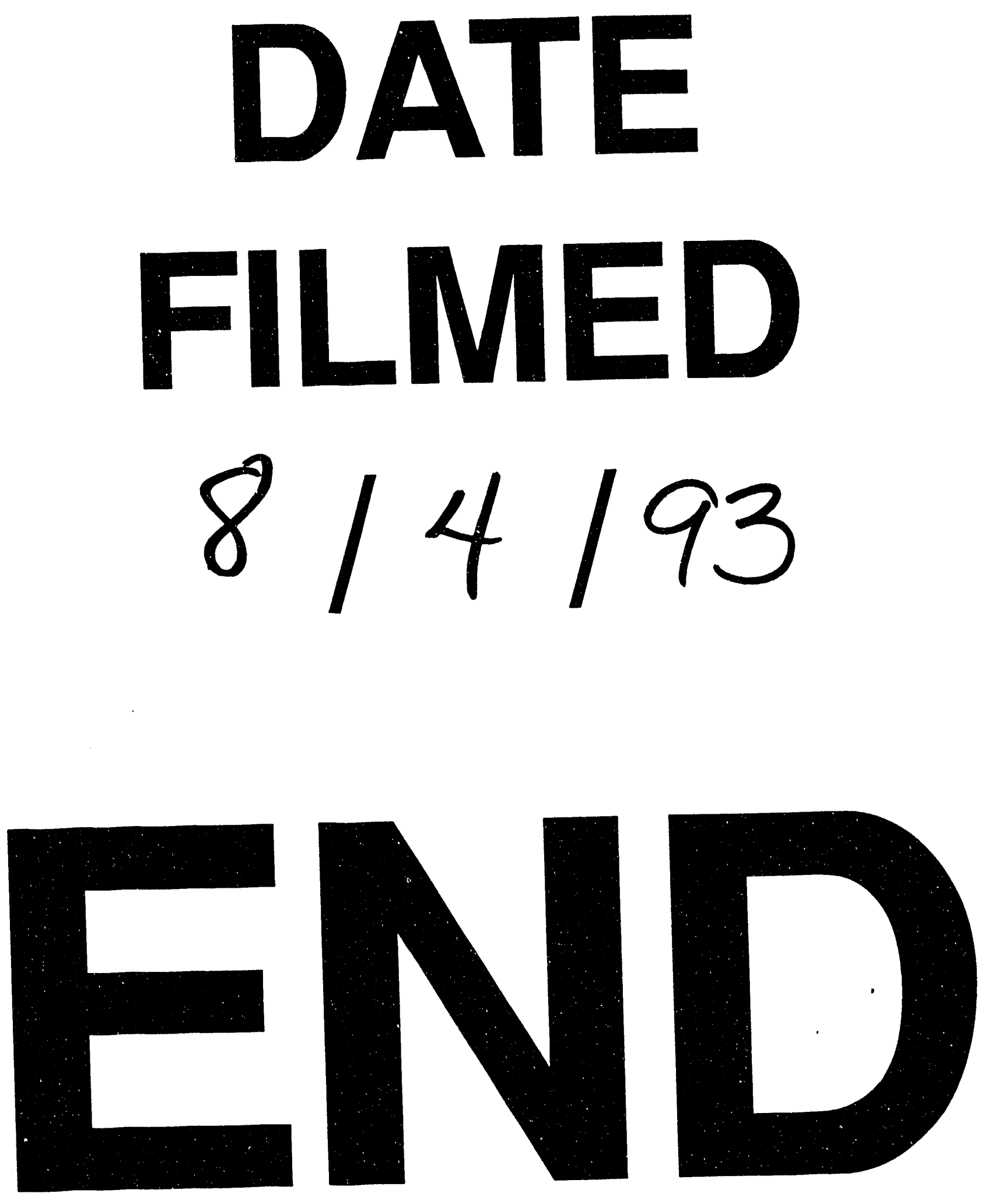
